\title{
ACCEPTABILITY AND LEVEL OF KNOWLEDGE OF HPV VACCINATION IN WOMEN AT SURAKARTA
}

\author{
Harsono Salimo, Hari Wahyu Nugroho, David Anggara Putra, \\ Aldilla Dinaresti \\ Department of Child Health, Faculty of Medicine/ Dr. Moewardi Hospital, \\ Sebelas Maret University
}

\begin{abstract}
Background: The main cause of cervical cancer is infection of Human Papilloma Virus (HPV). Every year there are 20,928 new cases of cervical cancer in Indonesia, with mortality of 9,498 patients. HPV vaccine has been recommended by the Indonesian Pediatric Society (IDAI) since the age of 10. The purpose of this study was to examine the level of knowledge and acceptability of HPV vaccination in women in Surakarta.

Subjects and Method: This was a cross-sectional study conducted in Surakarta in July 2017. A sample of 96 women aged 12-50 years were selected for this study by consecutive sampling. The dependent variables were acceptability and knowledge HPV vaccination. The data were collected by questionnaire.

Results: $43.75 \%$ of women had a good knowledge of HPV vaccination and $52.2 \%$ were willing to accept HPV vaccination.

Conclusion: Proportions of female adolescents in Surakarta who have good knowledge and willingness to accept HPV vaccination are fair.

Keywords: acceptability, HPV vaccination, knowledge, HPV infection, cervical cancer, human papilomavirus.

Correspondence: Aldilla Dinaresti. Department of Child Health, Faculty of Medicine/ Dr. Moewardi Hospital, Sebelas Maret University, Jl. Ir. Sutami 36A, Surakarta 57126. Email:dilladinaresti@gmail.com.
\end{abstract}

